\title{
DESAIN RAGAM HIAS PELAMINAN MELAYU RIAU SEBAGAI INSPIRASI INOVASI KRIYA BATIK
}

\author{
Nita Sahara $^{1^{*}}$, Agusti Efi ${ }^{* *}$, Reni Fitria ${ }^{3^{*}}$, Hadiastuti $^{4^{*}}$ \\ Konsentrasi Pendidikan Tata Busana Program Studi Pendidikan Kesejahteraan Keluarga \\ Jurusan Ilmu Kesejahteraan Keluarga Fakultas Pariwisata dan Perhotelan \\ Universitas Negeri Padang \\ Jl. Prof. Dr. Hamta, Air Tawar Padang, Kel. Air Tawar Barat, Kec. Padang Utara, Kota Padang, Kode Pos 25171 \\ Sumatera Barat. Indonesia \\ Email: nitachania@gmail.com
}

\begin{abstract}
Abstrak
Pelaminan Melayu adalah bagian dari tradisi budaya masyarakat Melayu yang berfungsi sebagai tempat duduk ketika pengantin wanita memiliki upacara pernikahan. Pelaminan Melayu dihiasi dengan sulaman tekat dengan menggunakan berbagai desain ragam hias Melayu. Pelaminan Melayu sebagai simbol perkawinan di Riau telah digunakan sebagai sumber inspirasi dalam pengembangan batik di Pekanbaru Riau, yang disebut batik tabir. Namun, tidak banyak orang yang tahu bahwa ide batik tabir terinspirasi dari pelaminan Melayu Riau. Oleh karena itu, penelitian ini bertujuan untuk mendeskripsikan bagian pelaminan Melayu yang menjadi inspirasi batik, desain ragam hias yang terdapat pada pelaminan Melayu Riau dan inovasi pada kerajinan batik. Penelitian ini menggunakan metode deskriptif dengan pendekatan kualitatif. Pengumpulan data penelitian dilakukan dengan menggunakan teknik wawancara, observasi dan dokumentasi. Informan ditetapkan dengan teknik snow ball sampling. Selanjutnya, data ditinjau dan dianalisis dengan langkah-langkah reduksi data, penyajian data, penarikan kesimpulan. Validitas data dilakukan dengan partisipan, observasi, triangulasi, pengecekan dan memberchek. Hasil penelitian menunjukkan bahwa: 1) bentuk Tabir salah satu bagian pelaminan Melayu berbentuk susunan garis-garis vertikal. 2) desain ragam hias Pelaminan Melayu Riau mengacu pada pola flora dan fauna. 3) Pelaminan Melayu sebagai inspirasi untuk inovasi batik. Konsep pola dasar batik berberupa garis-garis vertikal terinspirasi dari bentuk tabir belang pelaminan Melayu dan motif yang dirancang bersumber dari desain ragam hias yang terdapat di pelaminan Melayu Riau.
\end{abstract}

Kata Kunci: Pelaminan Melayu Riau, Desain Ragam Hias dan Batik

\begin{abstract}
Malay pelaminan is part of the cultural traditions of the Malay community that serves as a seat when the bride has wedding ceremony. Malay pelaminan is decorated with tekat embroidery by using various pattern of Malay ornament. Malay pelaminan as a symbol of marriage in Riau has been used as a source of inspiration in the development of batik in Pekanbaru Riau, called batik tabir. However, not many people know that the idea of batik tabir is inspired from Malay pelaminan of Riau. Therefore, this study aims to describe the shape of the Malay pelaminan, pelaminan ornament motifs and innovations to the craft of batik. This research used descriptive method with qualitative approach. Its data collection of the study was conducted by using the interview technique, observation and documentation. The informants were set with snow ball sampling technique. Furthermore, the data reviewed and analyzed by data reduction steps, presentation of data, drawing conclusions. The validity of data was done with the participation, the observation, triangulation, checking and memberchek.The results revealed that: 1) the shape of the Malay pelaminan as a whole is rectangular. 2) The decorative motive of Malay Pelaminan Riau refers to flora and fauna pattern. 3) Malay Pelaminan as a inspiration for batik innovation. Batik is the concept of vertical lines of the form tabir belang pelaminan shape, and it is designed from ornament in the Malay pelaminan of Riau.
\end{abstract}

Keywords: Riau Malay Pelaminan, Ornament and Batik

\section{PENDAHULUAN}

Indonesia merupakan negara kepulauan yang terdiri dari berbagai suku bangsa, yang memiliki adat dan kebudayaan berbeda-beda. Masing-masing adat dan kebudayaan di tiap daerah mempunyai keunikan dan ciri khas yang membedakannya dengan daerah lainnya. Hal ini dapat dilihat antara lain dari tata upacara adat, bahasa, kesenian, tingkah laku, 


\section{Gorga Jurnal Seni Rupa \\ Volume 07 Nomor 02 \\ p-ISSN: 2301-5942 | e-ISSN: 2580-2380}

arsitektur, makanan khas, dan tidak terkecuali cara berbusana maupun kerajinan tekstil.

Salah satu kerajinan tekstil yang memiliki pertumbuhan dan perkembangan yang sangat bagus di Indonesia adalah kriya batik. Kerajinan batik di Indonesia telah dikenal sejak zaman kerajaan Majapahit dan batik telah menjadi karya seni tradisional yang bermutu tinggi dan sudah dikenal seluruh dunia.

Kerajinan batik berkembang pesat dengan bermacammacam jenis, tergantung pada daerah masing-masing. Batik Riau yang berkembang di kota Pekanbaru ini merupakan batik tulis dan colet yang mempunyai kesamaan dengan batik Jawa akan tetapi terdapat inovasi pada pola batik dan motif menggunakan ciri khas yang menunjukkan motif-motif Melayu Riau.

Berdasarkan pengamatan dan informasi yang didapat dari sangar gerai batik Semat Tembaga, Batik Riau diberi nama Batik Tabir karena menggunakan desain tabir belang yang merupakan salah satu bagian dari pelaminan Melayu Riau. Bentuk tabir belang Pelaminan Melayu Riau dijadikan sebagai Sumber inspirasi inovasi pola dasar batik Riau ini.

Tabir belang yang berfungsi sebagai latar pelaminan juga digunakan dalam berbagai upacara-upacara adat Melayu Riau. Tabir belang digunakan pada upacara adat istiadat, perayaan hari besar Islam dan upacara duka. Tabir merupakan tirai penutup dinding pada bagian dalam rumah yang biasa dipakai untuk upacara-upacara adat. Tabir pelaminan ini terdiri dari potongan-potongan satin berwarna-warni dalam posis memanjang dari bawah ke atas (vertikal).

Bentuk tabir yang memanjang dan memberi kesan belang ini dijadikan sebagai sumber inspirasi inovasi kriya batik Riau. Selain tabir pelaminan, batik ini juga menggunakan motif-motif yang terdapat pada pelaminan Melayu Riau. Pelaminan Melayu Riau yang biasa digunakan dalam adat perkawinan Melayu Riau terdapay motif ragam hias yang merupakan motifmotif Melayu. Sebagian motif ragam hias tersebut kini telah dijadikan sebagai sumber inspirasi inovasi batik.

\section{KAJIAN TEORI}

Batik merupakan teknik corak dengan pemberian lilin dan warna dan memiliki sejarah yang sangat panjang, data awal di temukan di Jawa sebelah barat daya berupa gulungan daun lontar pada tahun 1520(Hamidin, Warming and Gaworski).
Seni batik ini pada umumnya banyak terdapat di kepulauan Jawa, seperti batik solo, batik pekalongan, batik Jogjakarta, batik Cirebon, dan lainnya. Batik ini kemudian berkembang keseluruh pulau di Indonesia seperti pulau bali, pulau Kalimantan, pulau Sulawesi dan pulau Sumatera.

Batik juga telah lama diproduksi di Sumatra yaitu di daerah Jambi, walaupun standar kualitas belum bisa menyaingi batik Jawa (Roojen, 1993:161). Selain batik yang berkembang di Jambi juga terdapat di daerah Sumatra lainnya. Batik setiap daerah tersebut memiliki ciri khasnya sendiri sesuai dengan daerahnya dan masih berkembang hingga sekarang.

Batik yang merupakan salah satu kerajinan tradisional yang tumbuh dan berkembang di Indonesia, secara otomatis batik Indonesia menjadi kerajinan tradisional milik Indonesia seperti halnya pematenan batik Indonesia yang disahkan oleh UNESCO sebagai budaya Indonesia. Hal ini memicu setiap daerah memproduksi batik untuk mempelihatkan kekhasan daerah masing-masing.

Riau juga tidak mau ketinggalan dalam memproduksi batik khususnya daerah Pekanbaru. Di Pekanbaru ini diciptakan batik yang bercirikan budaya Melayu. Batik yang terkenal di daerah pulau Jawa memiliki ciri khas kebudayaan daerahnya, begitu pula batik yang diproduksi di Pekanbaru ini tetap menggunakan teknik batik tulis akan tetapi pola dan motif diinovasi sesuai dengan kebudayaan Melayu.

Nilai budaya Melayu Riau umumnya berpuncak dari tiga aspek yang dominan, agama islam, adat dan tradisi Melayu (Budisantoso, 1986:423). Bagi orang Melayu Riau, pelaksanaan upacara adat perkawinan pinangan terdiri dari beberapa tradisi seperti merisik, meminang dan sebagainya termasuk diantaranya acara yang disebut dengan menggantung yaitu salah satu proses pemasangan pelaminan(Jamil, 2008:30).

Pelaminan dengan segala perlengkapannya merupakan perangkat adat dan hasil seni budaya masyarakat pendukung kebudayaan suatu daerah tertentu, seperti halnya di Kota Pekanbaru masyarakat Melayu menggunakan pelaminan Melayu Riau. Pelaminan Melayu ini merupakan perangkat kebesaran adat yang digunakan untuk melaksanakan adat istiadat Melayu dan keberadaan pelaminan tersebut tidak dapat dipisahkan dengan aturan dan ketentuan adat.

Pelaminan Melayu Riau memiliki beberapa bagian dengan bentuk yang berbeda-beda dan motif ragam 


\section{Gorga Jurnal Seni Rupa \\ Volume 07 Nomor 02 \\ p-ISSN: 2301-5942 | e-ISSN: 2580-2380}

hias tertentu. Salah satunya tabir belang pelaminan yang berfungsi sebagai pelindung atau penyekat sesuatu (Yatim, 2001:291). selain itu tabir dipergunakan dalam berbagai upacara-upacara adat Melayu Riau. Tabir belang digunakan pada upacara adat istiadat, perayaan hari besar Islam dan upacara duka. Tabir yang dianggap sebagai symbol melindungi marwah masyarakat Melayu.

Bentuk tabir yang memanjang dan memberi kesan belang ini dijadikan sebagai sumber inspirasi inovasi kriya batik Riau. Selain tabir pelaminan, batik ini juga mengunakan motif-motif yang terdapat pada pelaminan Melayu Riau. Pelaminan Melayu Riau yang biasa digunakan dalam adat perkawinan Melayu Riau terdapat ragam hias Melayu.

Ragam hias dipenuhi dengan berbagai motif yang disusun sedemikian rupa sehingga memperindah suatu hiasan. Motif adalah desain yang dibuat dari bagianbagian bentuk, berbagai macam garis atau elemenelemen (Suhersono, 2006:10). Motif ragam hias yang terdapat pada pelaminan Melayu Riau merupakan motif-motif Melayu. Motif hias tersebut dapat dibagi menjadi beberapa jenis yaitu motif geometris, motif manusia, motif fauna, motif flora dan benda lainnya (Hoop, 1949). Sebagian motif ragam hias yang terdapat pada pelaminan tersebut kini telah dijadikan sebagai sumber inspirasi inovasi batik.

Pada tahun 2005 Ketua Dekranasda Provinsi Riau mendorong tumbuh dan berkembang kerajinan batik, dengan mengangkat batik tabir yang ada di Pekanbaru sebagai batik Riau. Namun permasalahan yang terjadi pada saat ini yaitu pengembangan tabir yang merupakan salah satu bagian pelaminan dan motif ragam hias pelaminan Melayu Riau sebagai inspirasi desain batik tidak begitu dipahami oleh masyarakat Melayu Riau sehingga motif tradisi banyak terjadi pergeseran.

Penelitian ini bertujuan untuk mengungkapkan (a) bentuk Tabir Pelaminan Melayu Riau yang menjadi inspirasi Batik Tabir, (b) Motif Ragam hias yang terdapat pada pelaminan Melayu Riau di kota Pekanbaru, dan (c) Desain Ragam hias Inovasi batik yang bersumber dari pelaminan Melayu Riau di kota Pekanbaru.

\section{METODE PELAKSANAAN}

Penelitian ini menggunakan metode penelitian deskritif dengan pendekatan kualitatif. Metode kualitatif dipergunakan untuk mendeskripsikan data yang diperlukan dalam penelitian ini yaitu tentang tabir pelaminan Melayu Riau dan ragam hias dalam pelaminan serta variasinya terhadap batik Tabir. Penelitian ini memanfaatkan pendekatan kajian budaya sebagai pendekatan yang utama.

Lokasi penelitian yaitu provinsi Riau khususnya Kota Pekanbaru. Penelitian ini dilakukan pada tiga sanggar Pelaminan dan sanggar batik yang memproduksi batik tabir serta diperkuat oleh budayawan setempat. Pemilihan informan menggunakan teknik "snowball sampling". Sedangkan teknik pengumpulan data dilakukan dengan cara observasi pada daerah setempat, wawancara dengan beberapa nara sumber dan melakukan studi dekumentasi serta studi kepustakaan.

Teknik pemeriksaan keabsahan data dilakukan dengan mengkomfirmasikan data yang telah diperoleh dari hasil observasi atau pengamatan, data yang diperoleh melalui wawancara dan dokumentasi. Data disusun dan diolah secara sistematis, disajikan dengan deskriptif, dan dianalisis secara kualitatif. Data dianalisis dengan menginterpretasikan data yang ada secara terus menerus yang dimulai sejak awal penelitian hingga akhir penelitian sehingga memperoleh makna.

\section{HASIL DAN PEMBAHASAN}

\section{Bentuk Tabir Pelaminan Melayu Riau}

Berdasarkan penelitian di beberapa sanggar pelaminan Melayu di kota Pekanbaru, ditemukan bahwa Pelaminan Melayu memiliki peranan penting pada setiap upacara perkawinan Melayu di kota Pekanbaru. Bentuk pelaminan Melayu seperti singasana raja. Pelaminan pada mulanya digunakan sebatas tempat terhormat bagi para raja atau bangsawan Melayu, akan tetapi sekarang sudah menjadi kebiasaan dipakai untuk upacara perkawinan, yang diibaratkan sebagai upacara "raja sehari'.

Secara garis besar, pelaminan Melayu Riau berbentuk persegi panjang memiliki ruang pada bagian dalamnya dan terdapat beberapa bagian yang mehiasi pelaminan. Di daerah Melayu Riau, Pelaminan ini disebut juga dengan gerai besar, begitu juga di kota Pekanbaru.

Pada pelaminan Melayu Riau yang disebut juga dengan Gerai Besar terdapat bagian di dalamnya yang menjadi inspirasi pada inovasi batik di Riau, yaitu; Tabir Belang yang berbentuk persegi panjang dengan susunan garis vertikal. 

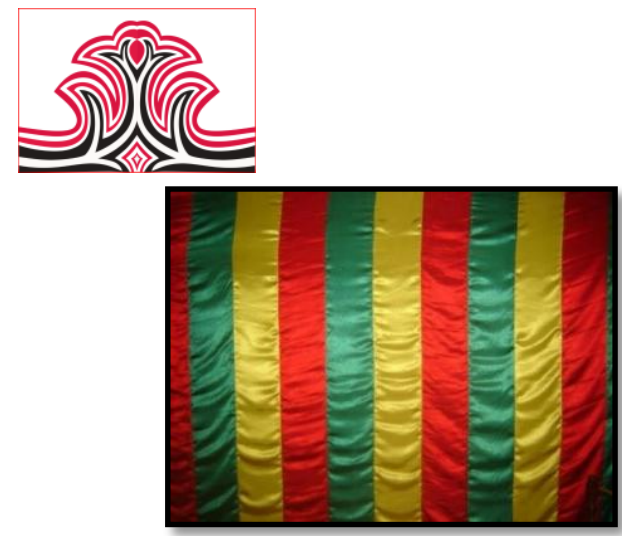

Gambar 1. Tabir Belang Pelaminan Melayu

Tabir Belang yang merupakan Salah satu bentuk bagian pelaminan Melayu ini menjadi sumber inspirasi pada inovasi batik yang diberi nama batik tabir yaitu bentuk susunan garis vertikal dari bentuk tabir belang pelaminan Melayu sebagai pola dasar desain batik.

\section{Motif Ragam Hias Pelaminan Melayu Riau}

Di dalam pelaminan Melayu Riau, terdapat beragam motif Ragam hias yang terbuat dari sulaman Melayu. Motif-motif Melayu distilasi dari bentuk-bentuk yang terdapat di alam Melayu ini, seperti bunga-bungaan, hewan, dan bentuk-bentuk alam lainnya. Pelaminan Melayu memiliki beragam motif hiasan Melayu. Motif ragam hias pelaminan berbentuk flora dan fauna yang ada di alam Melayu dan dihias dengan sulaman tekat Melayu. Pada dasarnya motif ragam hias sulaman ini terdapat juga pada kerajinan Melayu lainnya seperti ukiran dan tenunan. Sulaman tekat pada pelaminan Melayu biasanya menggunakan motif flora dan fauna. Malik (2004:33) mengatakan "Corak dasar Melayu Riau umumnya bersumber dari alam, yakni terdiri atas flora, fauna, dan benda-benda angkasa".

Dalam tradisi Melayu Riau, corak-corak dasar itu dikembangkan lagi dengan beragam variasi sehingga membentuk suatu perpaduan yang serasi. Bahkan ada yang menimbulkan nama-nama baru untuk motif yang dimaksud. Dengan demikian ragam hias sulaman Melayu memiliki motif dasar yang diciptakan dari bentuk asli yang terdapat di alam Melayu, kemudian dikembangkan lagi sehingga terbentuk motif baru dengan nama-nama yang bervariasi.

Motif ragam hias yang terdapat pada pelaminan Melayu terdapat berbagai macam motif Melayu. Pada setiap bagian pelaminan Melayu, tidak hanya terdapat Satu motif saja akan tetapi terdapat berbagai bentuk motif yang terkadang ditemui motif yang sama dalam bagian pelaminan yang berbeda. Motif-motif tersebut diberi nama sesuai dengan nama bentuk alam rekaannya dan ada juga yang diberi nama baru. Motif tersebut berbentuk motif flora dan terdapat juga motif

\section{Gorga Jurnal Seni Rupa \\ Volume 07 Nomor 02 \\ p-ISSN: 2301-5942 | e-ISSN: 2580-2380}

fauna. Nama-nama motif ragam hias pada pelaminan Melayu antara lain : 1) Motif Bunga Kesumba, 2)Motif Bunga Pecah Lapan, 3) Motif Bunga Mengkanang, 4) Motif Bunga Tanjung, 5) Motif Bunga Melur, 6) Motif Bunga Kuntum Tak jadi, 7) Motif Bunga Ceremai, 8) Motif Bunga Kundur, 9) Motif Bunga Cempaka, 10) Motif Bunga Kenduduk, 11) Motif Daun Labu, 12) Motif Air Mata Pengantin, 13) Motif Bunga Raya, 14) Motif Bunga Cengkeh, 15) Motif Bunga Kuntum Tak Jadi, 16) Motif Bunga Berembang, 17) Motif Bunga bintang, 18) Motif Bunga Matahari, 19) Motif Bunga Semangat, 20) Motif Pucuk Rebung, 21) Motif Bunga Seno, 22) motif Bunga Pak Mar Kembang Berdentum,23) Motif ikan-ikan, dan 24) motif Ayam Jantan.

Keberagaman motif yang terdapat pada pelaminan menambah keindahan bentuk pelaminan Melayu Riau. Begitu pula warna yang terdapat pada pelaminan dan motif menambah semaraknya pelaminan Melayu tersebut dan menjadi sumber inspirasi untuk motif batik tabir.

\section{Desain Ragam Hias Pelaminan Melayu menjadi Motif Batik Tabir}

Batik Tabir merupakan karya batik baru di daerah Riau. Batik Tabir diciptakan sebagai salah satu usaha untuk memperkenalkan budaya Melayu Riau yang idenya ditemukan dan dikembangkan oleh bapak Amrun Salmon yang diciptakan pada tahun 2004.

Batik ini merupakan karya inovasi yang menjadikan pelaminan Melayu sebagai sumber inspirasi. Menurut Syahfuddin (2009:2) Inovasi adalah kemampuan untuk menghasilkan sesuatu yang baru yaitu mendayagunakan kemampuan dan keahlian dalam mengembangkan karya tertentu. Inovasi yang merupakan pembaharuan dari hal yang sudah ada sebelumnya. Seperti halnya batik yang awalnya dikenal sebagai kerajinan tradisi daerah Jawa juga diciptakan didaerah riau khususnya kota Pekanbaru dengan konsep yang berbeda dengan batik Jawa. Batik tabir ini mengambil sumber inspirasi dari pelaminan Melayu yaitu pola batik dari bentuk salah satu bagian pelaminan Melayu dan motif ragam hias batik diambil dari motif ragam hias pada pelaminan Melayu yang. Ide ini dikembangkan menjadi sebuah karya baru berupa batik yang dapat disebut sebagai batik Riau. 

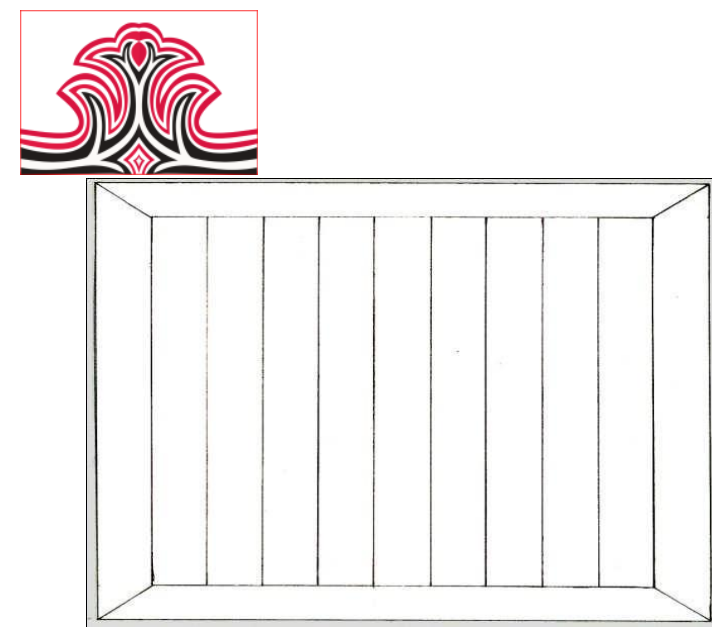

Gambar 2. Bentuk dasar Tabir Belang Pelaminan Melayu Riau

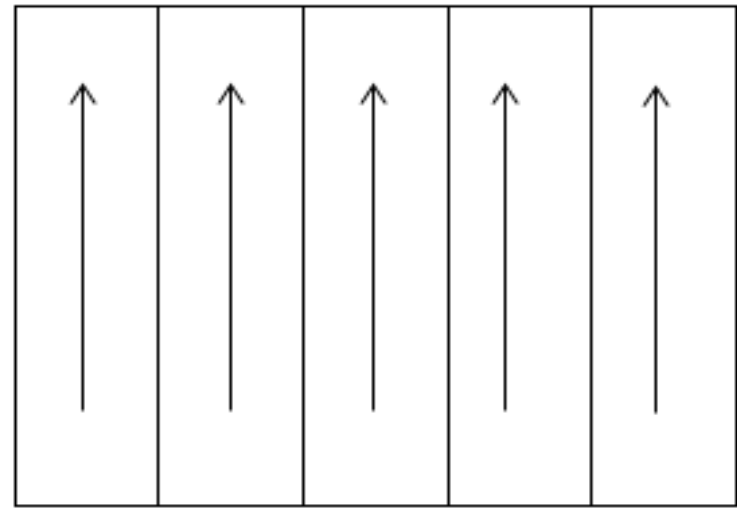

Gambar 3. Ilustrasi Pola Dasar Batik Tabir

Konsep pola batik diciptakan dari bentuk umum tabir yang terinspirasi dari tabir belang pelaminan Melayu Riau. Batik Tabir memiliki ciri seperti tabir belang pelaminan Melayu Riau yang memperlihatkan garis vertikal. Diantara garis vertikal tersebut dimanfaatkan dengan mengisi motif-motif Melayu Riau. Motif Batik Tabir diambil dari sulaman tekad yang terdapat pada pelaminan Melayu. Motif batik tabir diambil dari sulaman tekad dikarenakan desain sulaman ini lebih cocok dijadikan motif batik tabir, berbeda dengan desain tenun dan ukiran yang tampak lebih kaku. Motif yang sudah diberi nama dan dijadikan motif dasar batik tabir yaitu bunga bintang, bunga seno, bunga cempaka, bunga melur, bunga kenduduk, bunga mengkanang, bunga pak mar kembang bedentum, bunga kuntum tak jadi, bunga berambang, bunga kesumbo, bunga pecah delapan, bunga air mata pengantin, bunga raya, bunga tanjung, bunga semangat, bunga ceremai, bunga labu.

Motif-motif dasar ini merupakan penyempurnaan dari motif yang terdapat pada sulaman tekat yang terdapat pada pelaminan Melayu. Motif ragam hias dari sulaman tekat pada pelaminan Melayu menjadi sumber inspirasi yang diberi nama sesuai nama aslinya dan motif-motif ini distilasi lagi sesuai untuk desain motif batik. Motif yang diambil dari sulaman tekat yang dijadikan motif ragam hias batik tabir yang
Gorga Jurnal Seni Rupa

Volume 07 Nomor 02

p-ISSN: 2301-5942 | e-ISSN: 2580-2380

hanya motif berbentuk naturalis berupa motif bungabungaan.

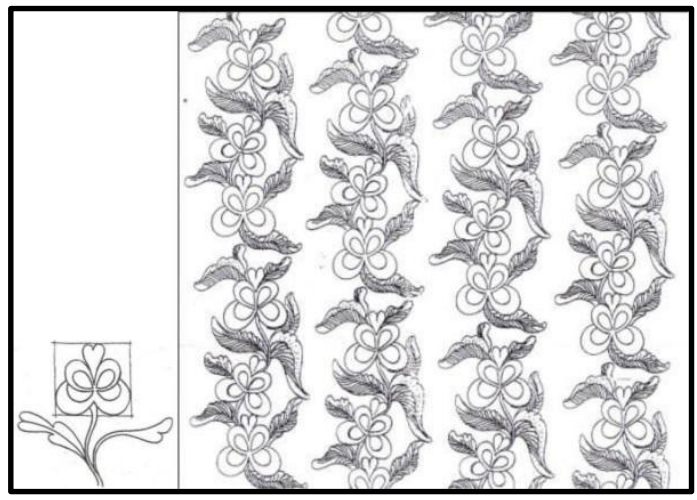

Gambar 4. Pengembangan Motif Pak Mar Kembang Berdentum pada Batik Tabir

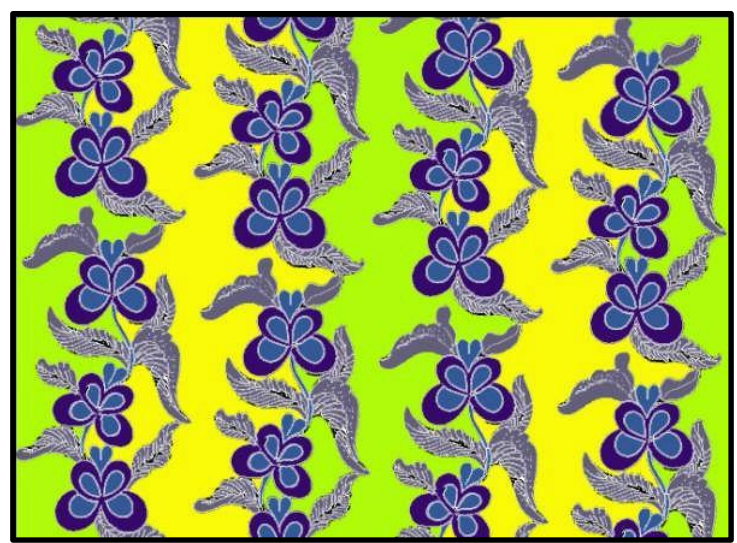

Gambar 5. Batik Tabir dengan Motif Bunga Pak Mar Kembang Berdentum

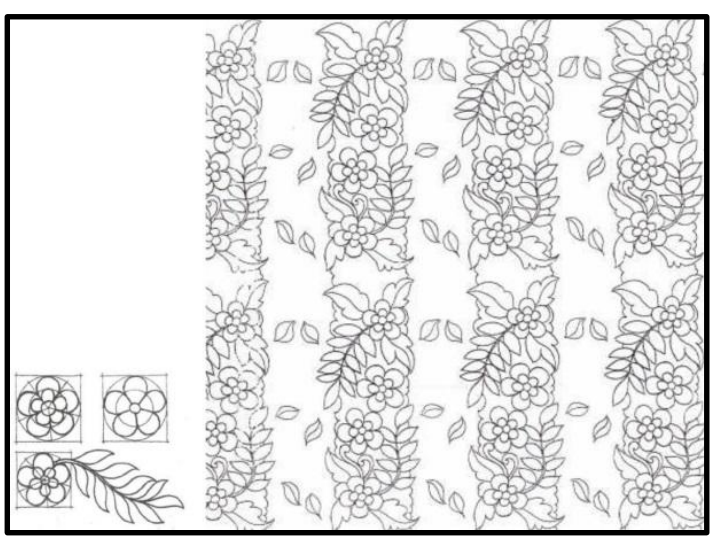

Gambar 6. Pengembangan Motif Bunga Ceremai pada Batik Tabir 

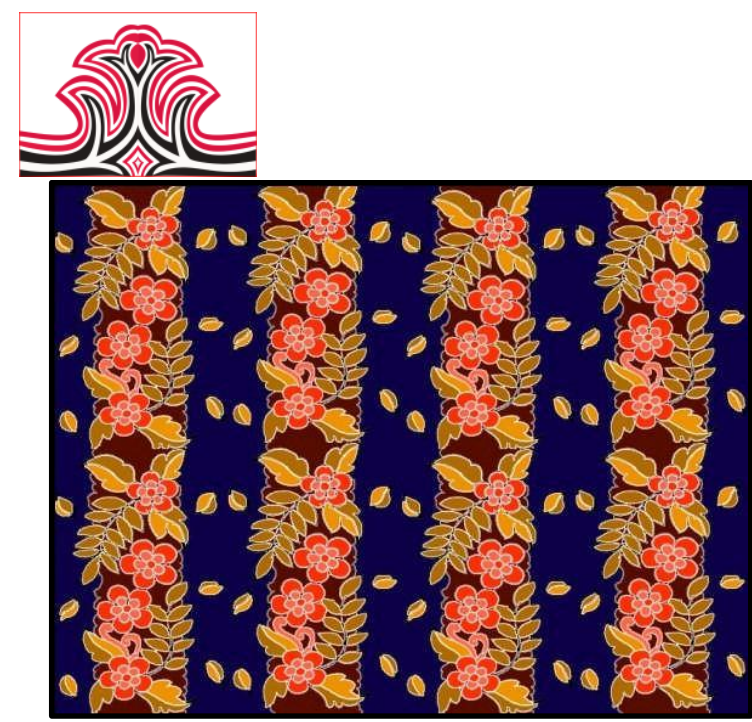

Gambar 7. Batik Tabir dengan Motif Bunga Ceremai

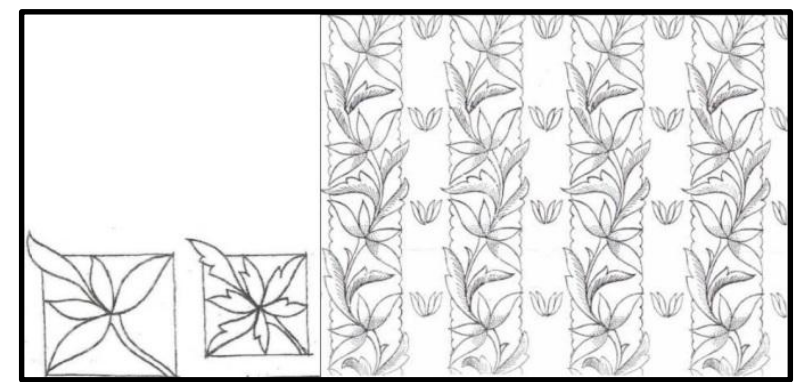

Gambar 8. Pengembangan Motif Bunga Cempaka pada Batik Tabir

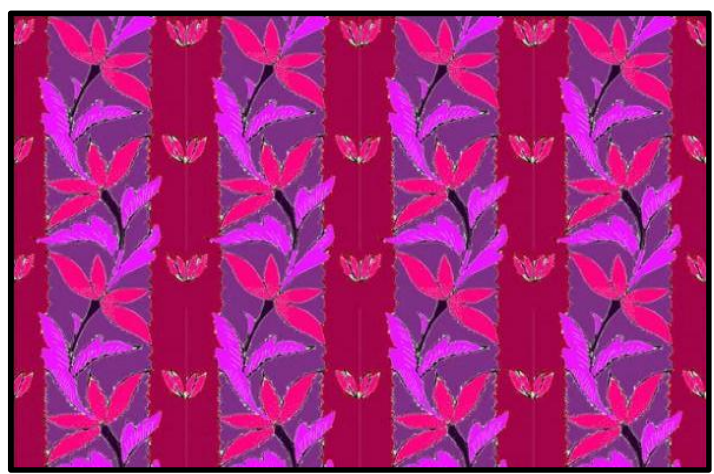

Gambar 9. Inovasi Batik Tabir dengan Motif Dasar Bunga Cempaka

Motif dasar Melayu yang di ambil dari pelaminan Melayu ini kemudian dikembangkan dan didesain memanjat mengisi bidang tabir dan menggunakan warna-warna yang berbeda pada suatu bidang sehingga memberi kesan seperti tabir belang pelaminan Melayu Riau.

\section{KESIMPULAN DAN SARAN}

Penelitian ini menghasilkan catatan budaya berupa desain batik tabir yang merupakan inovasi batik di daerah Riau khususnya Pekanbaru. Desain batik tabir ini mengambil sumber inspirasi dari tabir Belang yang merupakan salah satu bagian pelaminan Melayu dan desain ragam hias yang terdapat Pelaminan Melayu Riau. Hasil penelitian ini dapat diterapkan oleh penyelengara pendidikan yaitu pada mata pelajaran seni budaya untuk mengajarkan seni batik khususnya batik tabir sebagai kerajinan batik daerah Riau. Selain

\section{Gorga Jurnal Seni Rupa \\ Volume 07 Nomor 02 \\ p-ISSN: 2301-5942 | e-ISSN: 2580-2380}

itu pengembangan inovasi dapat dijadikan sebagai salah satu bahan dalam pengembangan seni kreatif.

Batik tabir yang telah disah sebagai batik Riau oleh gubernur Riau ini, baru diproduksi di kota Pekanbaru saja. Dengan adanya hasil penelitian ini, dinas perindustrian dapat mengembangkan batik dengan cara memberikan pelatihan-pelatihan kepada usahausaha batik tabir yang tetap berdasarkan dari motifmotif Melayu sehingga tidak terjadi pergeseran pada motif ragam hias Melayu.

\section{DAFTAR RUJUKAN}

Hamidin, Aep S. 2010. Batik Warisan Budaya Asli Indonesia. Yogyakarta: Narasi.

Hasanudin. 2001. Batik Pesisiran Melacak Pengaruh Etos Dagang Santri pada Ragam Hias Batik. Bandung: PT Kiblat Buku Utama.

Hoop, Van der. 1949. Ragam-Ragam Perhiasan Indonesia. Koninklijk Bataviaasch Genotschap Van Kunsten Wetenchappen. -:Jamil, Nizami. 2008. Adat Perkawinan Melayu Riau. Pekanbaru: CV. Suka Bina 